\title{
Struggle Values Analysis In Novel "Kami Bukan Sarjana Kertas" By J.S Khairen (2019)
}

\author{
Peter Manuputty \\ petermanuputty3@gmail.com
}

Ayani

ayanivictory1@gmail.com

\author{
Shania Patty \\ nhia.shania.27@gmail.com
}

Universitas Victory Sorong

\begin{abstract}
The purpose of this study are (1) to describe the value of struggle in novel Kami (Bukan) Sarjana Kertas by J.S. Khairen (2) describes the value benefits of internal struggle in novels Kami (Bukan) Sarjana Kertas. The method in this research is using descriptive method analytic by reading, taking notes, and analyzing every sentence in the novel which contains elements of literary sociology. The data source of this research came from novel Kami (Bukan) Sarjana Kertas by J.S.Khairen. The novel itself is produced from events social life of the community and the author himself. Therefore, the novel contains a variety the dynamics of life that occur in the community. This research is aimed at describes the sociological aspects of literature in the novel Kami (Bukan) Sarjana Kertas J.S. Khairen. The form of data from this research is in the form of sentences in the novel that contain elements of the values of struggle. The results of this novel research are to describe (1) the value of the willing sacrifice (2) the value of cooperation (3) the value of patience and never give up (4) the value of unity (5) the value hard work. The benefits are (1) the value of self-sacrifice (2) the value of cooperation (3) the value of patience and never give up (4) the benefit of the value of unity (5) the benefit of the value of hard work.
\end{abstract}

Keywords: Struggle Value; Sociological Aspects

\section{INTRODUCTION}

Literature is a work that comes from the imitation of human life. Aminuddin (2009: 80-81) argues that "literature is a structure. Structure on here in the sense that the work is a systemic arrangement of elements, which are intermediate the elements occur in a reciprocal relationship, determine each other, so the unity of elements in literature is not just a collection or pile of things or objects which are independent, but these things are interrelated, and interdependent". Creation separate literature was born in the social life of a certain area. Where is the literary work it describes people's life with all its activities. One of them is a novel work in which every 
chapter in the novel has an element imagination, creativity, ideas, and messages to be conveyed from the author to the reader.

The Big Indonesian Dictionary (1989: 134) states that "the word novel means essay prose that contains a series of stories about a person's life, the people around him by highlighting the character and nature of each behavior. Meanwhile, according to Goldmann (in Faruk 1999: 31) states that "distinguishing novels into three types, namely novels abstract idealism, psychological novel (decision romanticism), and educational novel". Febrianto and Anggraini (2019) state that "Novels are part of literary form has and contains the content of reality in which there is an event or events and behaviors experienced and made by humans (characters) ". Novels are capable of express the conflicts or life problems of the characters in a more profound way, yet subtle and simple. Apart from that, the novel is a series events with a background that are shown in a structured way, so that they are more in shape long compared to other fictional prose. Basically, novel uses are to provide entertainment to his readers. Novel is an expression as well a description of human life in a situation that is exposed to various kinds life problems. Social events and behaviors experienced by the community as well novelist himself. In analyzing events, events and behavior in society a sociological literary approach is needed. Azizi and Anggraini (2019) stated that "Novels can also be used as a reflection to shape human character, especially in social environment".

In the study of sociology of literature, which specifically examines a novel, is also found value of struggle. The value of struggle will usually be shown by someone when he is get a problem in his life. People who face these problems will struggle with the aim of being able to escape from these problems and with the hope of getting a more decent life again. The value of struggle will create a new attitude and mentality. Then next, guide the person to carry out an activity or action new and better way to deal with and solve life's current problems wrestle. Koentjaraningrat (1990:12) says that "Value is a conception that lives in the minds of most of the people of society regarding things that they should consider very valuable in life".

Based on the following understanding, in general it can be interpreted that the value of struggle is something that is good, valuable, valuable, liked, and noble which is contained in an action taken by someone to face life's problems or challenges, with the aim and hope that the action it can produce a new situation that is better and more useful than the previous situation.Overall, the novel Kami (Bukan) Sarjana Kertas by J.S.Khairen has been describes to the reader the values of a character's struggle in a novel the. This novel describes the struggles of a character named Affandi as his father Ogi along with Ogi himself and Gala. 


\section{LITERATURE REVIEW}

\section{Previous Study}

Kezia, Shepia (2017) wrote thesis entitled "Nilai-Nilai Perjuangan Tokoh Utama dalam Novel Penjaga Mata Air by Hidayat Banjar: Analisis Sosiologi Sastra" The purpose of this research is to describe struggle values in that novel. Method in this research is descriptive qualitative method. The result of this study show the values of the main character's struggle. In the novel Guardians of the Air is the values of being willing to sacrifice, the value of unity, the value of respect, the value patience and unyielding spirit, and the value of cooperation. The impact of the main character's struggles in the novel is to influence behavior and ways of thinking for the better.

Dhika Widyanintya (2011) wrote thesis entitled "Representasi Perjuangan Hidup Dalam Novel "Surat Kecil Untuk Tuhan". The purpose of this study is to represent the struggle for life in the novel "Surat Kecil Untuk Tuhan". In this study the authors used a qualitative research method, with Roland Barthes's semiological analysis approach. The subject of the research is novel "Surat Kecil Untuk Tuhan" and the object of research is the text that represent the struggle of life in the novel "Surat Kecil Untuk Tuhan". The corpus is all the text that represent the struggle of life in the novel little letter to god. The conclusion of this study is that there are nineteen that present the struggle values of life in the novel "Surat Kecil Untuk Tuhan".

\section{Novel}

Novel is a prose that contains a series of someone's life with others in around him by the character and nature of the performer. Tarigan (2011) states that the novel is a story with long enough paths to fill one or more books that work on them imaginative life of man and women. Kinds of novel are novel fiction, non-fiction, romance, horror, mystery, comedy, inspirational. Elements of novel are intrinsic and extrinsic.

\section{Struggle Value}

Sanusi (2015: 17) states that struggle values is a system based on components that interact, interrelate and interconnect. Through this understanding, values are things that refer to goodness and ugliness which function to control human to act according to regulations, both in religion, morality, social which reflects a beauty. The kinds of struggle value are: value of unity, value of willing to sacrifice, value of nationalism, value of tolerance. 


\section{METHOD}

\section{Design and Samples}

This study used analytical descriptive method that is to use how to read, take notes, and describe some of the problems in a novel. Descriptive research is a quantitative research method that attempts to collect quantifiable information for statistical analysis of the population sample. It is a popular market research tool that allows us to collect and describe the demographic segment's nature.

\section{Instrument and Procedures}

The main data of this study is "Kami Bukan Sarjana Kertas" By J.S Khairen (2019) novel. Supported books about problems of life struggle, as well as books on literary research. In other words, the researchers also carried out library study techniques namely by analyzing the contents. The procedure of collecting the data are as follows:

a. Carefully read the novel "Kami Bukan Sarjana Kertas" By J.S Khairen (2019).

b. Write the characters and characterization found in novel "Kami Bukan Sarjana Kertas" By J.S Khairen (2019).

c. Write the quotation of struggle Value found in novel "Kami Bukan Sarjana Kertas" By J.S Khairen (2019).

d. After the data is collected the researchers identifiy the data to words of struggle value.

\section{Data Analysis}

The technique of analysis data in this research are:

a. Review are data collected after reading novel novel "Kami Bukan Sarjana Kertas" By J.S Khairen (2019).

b. Classified the quotes to each kinds of struggle value.

c. Analysis each struggle value based on each kinds struggle value by interpreting

d. Make the result of research.

\section{RESULTS AND DISCUSSION}

The synopsis of novel "Kami Bukan Sarjana Kertas" By J.S Khairen (2019).

"Kami Bukan Sarjana Kertas" tell a story about seven new students at Dwi Eka Laksana University or abbreviated as UDEL. Initially, new students at the UDEL campus were formed in groups consisting of seven people. This group has one companion lecturer and must survive until graduation. The purpose of forming this group is so that students can get to know each other and remind each other of their dreams after graduating from the UDEL campus.

A group was formed consisting of Ogi, Randi, Arko, Sania, Juwisa, Gala and Cath. They come from many different faculties. Ogi, Randi and Arko came from the Faculty of Communication Sciences. Juwisa and Sania come from the Faculty of 
Economics. Meanwhile, Gala comes from the Faculty of Engineering. Cath herself did not study at the UDEL campus for too long because she chose to continue her studies in the Netherlands. Their small group was supervised by Mrs. Lira, a lecturer who graduated from S3 Animal Genetic Engineering in the United States.

Ogi is the laziest kid among everyone in his group. The reason Ogi wanted to study at the UDEL campus was because of the coercion of Randi Jauhari aka Mine. His best friend repeatedly told him to go to college for a better future in the future. Finally, Ogi accepted the mine's invitation. On the first day of college, they both got acquainted with Arko, Sania, Juwisa, and Cath. On that very day, their assistant lecturer, Mrs. Lira, came with lots of pizzas and two large black suitcases. Initially, Mrs. Lira gave the pizza to all the new students in the room. In the midst of the students enjoying pizza, Mrs. Lira suddenly asked a surprising question.

"Who feels the smartest here? Please raise your hands!"

Not a single student dared to raise their hand. They just got confused and stopped enjoying the pizza Mrs. Lira gave them.

"Then who feels the most stupid here? Please raise your hands!"

Without thinking, Ogi immediately raised his hand. Ogi admits that he is probably the dumbest person in this room. In addition, he actually had no intention of going to college if he wasn't forced by Mines. Especially after several days of college which turned out to be too much for Ogi. He thought the communication department was just talking but it was more than that. Finally, Mrs. Lira told Ogi to come out. Ogi came out of the room. When Ogi came out, Mrs. Lira also came out and locked the door of the room. The strange thing happened when all the students in the room screamed in fear. In fact, inside Mrs. Lira's two suitcases, large rats came out that immediately attacked all the students who were enjoying pizza. It seems that this incident had been arranged in such a way by Mrs. Lira as a form of introduction for new students at the UDEL campus. In addition, Mrs. Lira still had time to enjoy the incident behind the window with Ogi while issuing curses to all students who felt smart.

"Try those of you who feel smart in dealing with those rats! The world after you graduate will be more disgusting than those rats. " cried Mrs. Lira

Ogi himself still couldn't believe what he saw behind the window of the room with Mrs. Lira.

This novel is quite interesting because it tells about student life that is in tune with what I am experiencing today. What's more is the background of this novel which tells the story of a handful of people who struggle for the future even though they are forced to study at a private campus and are not as famous as the UDEL campus. This novel raises the awareness that life after graduate school is a life that is more disgusting than Mrs. Lira's pet rats that are always used when introducing new students. Like the word lecture is one of the many stepping stones to face the harshness of life in the future.

\section{Struggle Value in Novel “Kami Bukan Sarjana Kertas” By J.S Khairen (2019).}

Endraswara (2003: 79) states that "sociology of literature is research that is focuses on human problems because literature often reveals the struggles of mankind 
humans in determining their future, based on imagination, feelings, and intuition" Struggle is an effort that is done with all his might to obtain something that is hard to get. The struggle that will become a study in a research novel this is the struggle waged by the characters in the novel Kami (Bukan) Sarjana Paper in the face of the problem at hand. Struggle is an effort that is done with all his might to obtain something that is hard to get. The struggle that will become a study in a research novel this is the struggle waged by the characters in the novel Kami (Bukan) Sarjana Paper in the face of the problem at hand. Apart from having a formal meaning, the term struggle also has a meaning activity, what is meant is an activity to try something in order to achieve it a goal using mind, willpower, and extra energy, even if needed by fighting each other or even fighting.

The value of struggle is a value that is inherent in people's life us from time immemorial. Since the colonial era, our nation has practiced a struggle in order to survive and what is prioritized is to be able to expel invaders from the country we now live in, and until recently, though our nation is now independent, but life's problems keep changing come to our lives every day. Because it was when we were alive, then life's problems will also always come to us, and that also means that the struggle will continue and also the value that exists in that struggle will always follow the steps of our life. Consciously or unconsciously this value will appear or just be born when we face a problem. And that encouraging our people to continue to struggle, there must be several figures in it. So also with several characters in the novel Kami (Bukan) Sarjana Kertas. So, value the struggle that is being studied is the value of the struggle shown by the figures contained in the novel and how are the benefits of the value of the struggle shown by the characters in the novel Kami (Bukan) Sarjana Kertas for solving a problem faced. The characters get a problem that is difficult to solve, then from it is necessary to do a struggle to solve it.

The value of the struggle is the result of a human's effort in living it an experience, a challenge, a problem in this life. The value of struggle can be serve as an illustration of how big a person's struggle in life. Human life cannot be separated from human struggle itself. Guidelines the struggle for life takes the form of a real action. Often also described with a way of taking an action or taking action to confront or changing a condition. What is meant by the aspect of struggle in this context is soul, real action or action, and the spirit shown by the characters in the novel this, and the value of the struggle carried out by these figures.

The magnitude of the life problems experienced by the characters made him required himself to do a great struggle too. Characters shows the value of struggle in actions and efforts to get through life's problems who come one after another. The values of struggle in Novel Kami (Bukan) Sarjana Kertas are:

\section{Value of Cooperation}

Lewis Thomas and Elaine B. Johnson (2014: 164) stated that "cooperation is a grouping that occurs among living things that we know. Work together or 
learning together is a team process (group) in which the members support and rely on each other to achieve a consensus. A classroom a very good place to build group (team) skills, which you need later in life ". The value of cooperation is very, very important for us to have at in our life in society. We must be able to cooperate with people others who are around us. Humans are not able to live alone, humans are created to help each other. Whether it's in the family, in society or wherever we are are located. We must be willing and able to cooperate with others. Something like this really needs to be done so that someone can get a work that is best. The value of cooperation is very important to be applied in someone with other people, because if everyone can be invited to work together, then every job will be felt become lighter or even easier and can be completed quickly and maximum. Because the value of cooperation teaches humans to help each other in doing a job. In this novel there is also the value of cooperation as in the following sentence.

Indonesian Version: "jadi aktivitas kita selama di sin, bakalan dimonitor terus dong?" Tanya ogi. Gala mengangguk. Segera Ogi mengeluarkan laptopnya. Mengutak-atik sesuatu. "Arko,lo bisa ambil foto-foto sesuai sudut tiap-tiap CCTV gak?" "hah?maksud lo botak?" "Gak asyik aja kan, liburan kita dihantu CCTV." "Oh gue ngerti maksud lo. Tapi kalau foto doang, gak ada yang gerak, bakal dicurigai dong?" Arko bingung. Mereka semua paham dan segera berkeliaran. Mengambil rekaman tiap sudut ruangan dan halaman bahkan hingga pantai sesuai sudut CCTV. Sesekali mereka juga melakukan gerakan acak didepan CCTV agar terlihat natural. Ini semua kemudian mereka serahkan pada Ogi dan jadi bahan untuk meretas sistem CCTV vila ini. Tak sampai lima belas menit, ia berhasil membobol sistem CCTV vila. Hasil video yang diambil teman-temannya ia gunakan sebagai tipuan. (Khairen, 2019:116-117)

\section{English Version:}

"So our activities while here, will continue to be monitored, right?" Asked ogi. Gala nods. Ogi immediately took out his laptop. Tinkering with something. "Arko, can you take photos according to the angle of each CCTV?" "Huh? You mean bald?" "It's not fun, our vacation is haunted by CCTV." "Oh, I understand what you mean. But if it's just a photo, no one moves, will you be suspicious?" Arko is confused. They all understood and immediately roamed. Take footage of every corner of the room and yard even to the beach according to the CCTV angle. Every now and then they also do random movements in front of the CCTV to make it look natural. They then left this to Ogi and became the material to hack into the CCTV system of this villa. In less than fifteen minutes, he managed to break into the villa's CCTV system. He used the results of videos taken by his friends as a trick. (Khairen, 2019: 116-117) 


\section{The Value of Self-Sacrifice}

In realizing his desires, humans must be doing a struggle for realize what he really wants or whatever he aspires to. Even willing sacrifice to realize these desires like what Ogi's father did inside Episode 2: The Gold chair.

Indonesian Version:

Babe pergi mencari kursi dari emas untuk kuliah ogi. Babe meninjam emas adiknya,mpok Titis untuk dijual. "ye enggak apa-apa, bang,buat ponakan aye ini," celetus mpok Titis pada Affandi. Babe Affandi kemudian pergi menjual emas itu dan pulang memagut tas berisi uang. (Khairen, 2019:18)

\section{English Version:}

Babe went in search of a gold chair for college ogi. Babe borrowed his sister's gold, Titis's group to sell it. "Yeah, it's okay, bro, for my niece," Titis said to Affandi. Babe Affandi then went to sell the gold and came home to pick up the bag containing the money. (Khairen, 2019: 18)

The sentences above describe that the struggle of a father for the sake of their children's education is even willing to sacrifice for the sake of looking for massage here and there and on finally borrowed some gold from his younger brother. The gold is then sold for a fee his son's education named Ogi. Even as much money as it can be used for his father's business capital or to rent a larger shop.

\section{The Value of Patience and Never Giving Up}

Muhammad (2002) states that "patience can be interpreted as steadfast, namel the fortitude of a person in the face of something difficult, heavy and bitter one must accepted and faced with full responsibility". Value of patience and spirit of abstinence giving up is a very important thing. Despite our many struggles experience failure in its early stages, but we must remain passionate and patient, even we must instill an unyielding attitude in our every struggle. Because with unyielding attitude and keep on trying, one day we will succeed in our struggle. Unyielding attitude is a key to gain success in a struggle. This figure named Gala in his life shows the value of patience and never give up. As in sentences following.

Indonesian Version:

Tunggu punya tunggu, berhari-hari, berminggu-minggu, ternyata ide tak digubris sama sekali. Mana mau orang memakai jasanya yang bahkan belum teruji sekalipun. Gala cari lagi peluang lain. Ia beli tiket pesawat ke Batam. (Khairen, 2019:139).

English Version: 
Wait, have waited, days, weeks, apparently the idea was ignored at all. Where do people want to use their services that have not even been tested. Gala look for another opportunity. He bought a plane ticket to Batam. (Khairen, 2019: 139).

The following sentences show that this character named Gala is very tenacious and practice the value of patience and never give up. Although the services no one wants wear it to stay patient, stay enthusiastic, and never give up and then try looking for luck in other fields and hoping to get luck in other fields the. The value of patience and never giving up will make everyone not easily pessimistic and does not give up easily before he is no longer able to pursue something he wants.

\section{The Value of Unity}

The value of unity includes the understanding of the unity of the various features which are very diverse and become a unity or unity. Indonesian society kinds of ethnic groups and cultures with diverse customs, as well various kinds of religions that are embraced, the diversity of languages used too make it easier to allow the differences to break apart. However these differences can be omitted when all parties have a very thick sense of unity and feeling intact.

The value of unity is a value that is very necessary for everyone to have. Because the value of this unity is able to prevent the division caused by it the difference one has to another. Hence, the value of that unity it is very important for us to have, because we are able to maintain and keep wholeness so as not to divorce. The value of unity can also guide us in facing every problem. With way together. If we face a problem together, then problems that were so heavy will become lighter and will become easier to complete. Because we have other people who can help us to deal with the problem, in other words we will have friends or even best friends to share.

In this novel there is also a value of unity carried out by the character named Gala, Mine and Juwisa as in the following sentence.

\section{Indonesian Version:}

Muncul pula ide berbasis teknologi. Start-up. Gala yang punya ide. "how about no?" tolak ranjau. "sekarang apa-apa stert-up, udah latah banget seтua anak muda. Dikit-dikit start-up, dikit-dikit startup. Biar keren aja kan sebenarnya? Ini ada info menarik. Sembilan dari sepuluh start-up, gagal di tahap awal. Cuma karena ngeliat yang udah besar-besar, tergiur aja buat bikin juga? Not me." "bukan begitu Randi, menurut aku, start-up itu hanya cara menjalankannya. Inti bisnisnya ya beda-beda. Lagian, teknologi, apalagi smartphone sangat membantu banget kan sekarang” papar Juwisa rendah. (Khairen, 2019:145) 
Juwisa memaparkan dan mencoret-coret kertas. Ia selesai mencoret berbagai cabang dan media seni. "Kita mempertemukan dua golongan ini, di situs ini, para penyanyi, koreografer, penari, pelukis, penulis, penyair, pemain band, fotografer..." (Khairen, 2019:146) "Setuju. Kalau gitu kita focus ke jasa apa?" Tanya gala. Saat bersamaan, juwisa masih menulis, membuat bagan-bagan, tandatanda panah dan coretan lainnya. (Khairen, 2019:146)

\section{English Version:}

Technology-based ideas also emerged. Start-up. Gala has an idea. "How about no?" repel mines. "Now, nothing stert-up, all young people are really talkative. Little start-up, little start-up. Just to be cool, right? Here is some interesting information. Nine out of ten start-ups, fail in the early stages. Just because you see the already big one, are you tempted to make it too? Not me. " It's not like that, Randi, in my opinion, start-up is just a way of running it. The core of the business is different. After all, technology, especially smartphones is very helpful right now, "said Juwisa lowly. (Khairen, 2019: 145)

Juwisa explained and scribbled paper. He finished scribbling various branches and art media. "We bring together these two groups, on this site, singers, choreographers, dancers, painters, writers, poets, band players, photographers ..." (Khairen, 2019: 146) "Agree. If so, what services should we focus on?" Asked gala. At the same time, Juwisa was still writing, making charts, arrows and other scribbles. (Khairen, 2019: 146)

In this case, there seems to be a debate and mutually reinforce the idea but also did not find common ground. Then they tried to unite his mind for a new innovative idea. In the end they came up agreement on the idea of the innovation. The quote above also states that the Gala character is not alone think of the latest innovation ideas but involve another character named Mine and Juwisa in order to find a way out and find new ideas. In the end they are also agreed to carry out the idea presented by another character named Juwisa.

\section{The Value of Hard Work}

Hard work is an activity that is carried out in a sincere manner without tirelessly or stopping for a moment for the sake of a target that he wants and also always prioritizes a satisfaction of results in every work he does. Hard work can be interpreted as working earnestly in order to achieve a desired goal. They are able to use their time well so that sometimes they forget about time, don't recognize distances, or even forget about the difficulties they are facing. They are very excited for good and maximum results. As in the following sentence. 


\section{Indonesian Version:}

Ogi benar-benar membuka dan membaca buku. Dosen datang, mulai menjelaskan dan corat-coret rumus di papan tulis. Sebenarnya, sama saja, tak satupun Ogi mengerti awalnya. Namun karena ini bukan ujian, ia masih boleh tengok dan Tanya kanan kiri. Untung Arko dan Ranjau dengan senang hati menjelaskan dan menunjukkan cara mengerjakan soal statistika sosial lanjutan, alias stasialan ini.(Khairen, 2019:66)

Indonesian Version:

Ogi actually opened and read a book. The lecturer came, started explaining and scribbled the formulas on the blackboard. Actually, it's the same, none of Ogi understood at first. However, because this is not a test, he can still look and ask right and left. Untung Arko and Mine are happy to explain and show how to do this advanced social statistics problem, aka stationary. (Khairen, 2019: 66)

The quote above explains that the character named Ogi was originally lazy followed this course but in the end he followed it carefully. This Ogi character learn from his mistakes during the exam some time ago who get the score bad because rarely attend lectures. At that time, Ogi's character began to be diligent and trying hard in order to get a good grade on the upcoming exam.

The value of working hard that is contained in Ogi also shows that each humans must do everything they can actively and never give up for what they aspire to. The value of working hard that Ogi has shown can be a good example and can follow because many things we learn from this Ogi figure.

\section{CONCLUSION}

As with the explanation above by using a novel entitled Kami (Bukan) Sarjana Kertas by J.S. Khairen about the value of struggle, then It can be concluded that there are five values of struggle, namely the value of self-sacrifice, the value of cooperation, the value of patience and never giving up, the value of hard work and the value of unity. From within the novel there are many values of struggle that have been described above. All the values of this struggle are useful for solving the problems that have been faced by several figures. It is these five values of struggle that make up the figures succeeded in solving the problems that came to him in his daily life. In the novel above, several problems are described descriptively and it is clear that in the end it can be resolved thanks to what has been described earlier. In this novel, there are actually a lot of values of struggle found in several episode in it. The values of struggle in this novel are exemplary for readers because it is very useful for the life of the reader and the reader will understand what life means when studying the values of the struggle. And it is hoped that the reader will be able to practice the values described above. 


\section{REFERENCES}

Depdikbud. 1995. Kamus Besar Bahasa Indonesia. Jakarta: Balai Pustaka.

Dhika, W. 2011. Skripsi "Representasi Perjuangan Hidup Dalam Novel "Surat Kecil Untuk Tuhan

Khairen, J. (2019). Kami (Bukan) Sarjana Kertas. Jakarta Selatan: Bukune Kreatif Cipta.

M.G., C. T. (2019). Nilai Perjuangan Tokoh Sabari Dalam Novel Ayah Karya Andrea Hirata. Medan: Universitas Sumatera Utara.

http://research-report.umm.ac.id/index.php/SENASBASA/article/view/3226/2914

https://www.dosenpendidikan.com/pengertian-sastra-menurut-15-para-ahli-dan-

$\underline{\mathrm{kbbi} /}$ 